\title{
The Influence of Innovation Chemistry Practicum Guide and Kit Integrated Guided Inquiry Model for on Students Skills for Class XI Second Semester Senior High School
}

\author{
Nur Akmalia \\ Postgraduate Program of Chemistry Education \\ State University of Medan \\ Medan, Indonesia \\ maia.akmalia.11@gmail.com
}

\author{
Ramlan Silaban \\ Postgraduate Program of Chemistry Education \\ State University of Medan \\ Medan, Indonesia
}

\author{
Mahmud \\ Postgraduate Program of Chemistry Education \\ State University of Medan \\ Medan, Indonesia
}

\begin{abstract}
This study was aimed to developing valid chemistry practicum guide and kit for class XI second semester senior high school integrated inquiry model according to BSNP criteria and knowing the effectiveness of the chemistry practicum guide and kit integrated guided inquiry on student skills. The sample in this study is $\mathbf{2}$ chemistry practicum guidebook with different publisher of class XI second semester Senior High School, the practicum guide that has been developed, 5 chemistry teachers, 5 peer review, 2 lecturers of postgraduate chemistry education program of Medan State University, and 22 students of class XI IPA Senior High School Muta'allimin Aceh Besar. Sample selection using purposive sampling technique. This type of study is research and development with ADDIE. Data analysis technique in this study is descriptive quantitative. Data obtained from questionnaire of validity analysis guide practicum according to BSNP criteria, questionnaire questionnaire of validity analysis practicum kit according to BSNP criteria, and student skill observation sheets. The result of validity analysis of the practicum guide used in the school has an average value of 3.01 with the valid category, but there are some components of the practicum guide that need to be developed. The developed chemistry practicum guide has an average grade of 3.54 with very valid category. The developed practicum kit has an average grade of 3.54 with a very valid category. The effectiveness of use chemistry practicum guide and kit on student skills shows an average score of 79,92 means that the average value of student skill is greater than the KKM score of 73 .
\end{abstract}

Keyword-practicum guide, practicum kit, guide inquiry model, student skills.

\section{INTRODUCTION}

Chemistry subjects have the same characteristics as IPA, because it is one field of science science. The explicit demands and targets of the chemistry curriculum are the balance of individual students' abilities between their intellectual and physical skills. Therefore, chemistry teachers should conduct teaching and learning activities through methods that provide individualized experience directly to students [9]. The process of providing direct experience in learning to students aims to develop the competence to understand learning scientifically. Zidny, et al. (2017) states that chemistry is a science that needs to prove experiments that have two things that are very related and inseparable, namely chemistry as a product (chemical knowledge in the form of facts, concepts, theories and principles) and the process (scientific work).

Practicum has an important role in science learning especially chemistry learning because chemistry is an experimental science that can not be learned only through reading, writing, or listening only. In accordance with a statement from [1] which states that the lab is an important part of science education. It helps students to develop their understanding of science, studying evidence-based science and gaining hands-on experience is very important for students to progress in science. Students should be given the opportunity to conduct experiments and investigations that are fun and varied. Practicum conducted in the laboratory, [6] also provide the opinion that the laboratory has an important role in science education, and science educators have suggested that there are many benefits in learning derived from the use of laboratory activities. In the late 1970s and early 1980s. 
Good practicum implementation can not be separated from the availability of practicum guides used as guidance students in practicum activities. According to [14] of chemistry in the learning process in the form of manual of chemistry practicum is very necessary, and the need of science-based learning processbased science process to improve students' scientific skills. The practicum guide aims to guide students in doing the lab and to help the teacher in achieving the learning objectives. The practicum guide was compiled and written by a group of teaching staff who handled the practicum and followed the rules of scientific writing [7].

Some school-related problems include inadequate equipment or chemicals, no laboratory, insufficient time, no laboratory assistant, practical work is dangerous, security rules impede practical work, practical work is not checked, and teachers feel poorly prepared or has no experience [3]. According to [4] to do practical activities students are given a photocopy of worksheets and sometimes teachers write directly step on the board on the day of practice. The instruction in the given guide limits the creativity in doing the lab so that learning becomes less meaningful. It is also due to a practicum guide that has not been integrated with a learning model sutau. Xu and Talanquer (2012) also stated that laboratory activities in schools and college education are relatively small, which is based on the students' skills are still not good and the guide is not enough at the time of the lab.

Efforts are made to overcome the problem is to integrate a model of learning into the practical guide, one of the models that can be integrated is guided inquiry which is then implemented in the form of practical guides. According [11] the laboratory inquiry approach emphasizes the whole scientific process, where learners have the opportunity to identify problems from their observations, formulate hypotheses, plan procedures and conduct investigations, explain facts obtained in experiments, and convey conclusions.

Another effort to overcome the above problem is to conduct a chemical lab with a micro scale. Micro-scale practice is practicum with tools and materials used also with designs of smaller size than the equipment used in the usual lab. Tools and materials used, packed in a box commonly called a practicum kit [12]. [5] States that the practicum kit is one of the practical media that can be used in classroom learning. The practicum kit is a set of practical tools packaged in a box containing practicum tools. Implementation of a chemistry learning course with a lab kit becomes easier, simpler, less intimidating, safer for health, and can reduce the risk of laboratory accidents.

Based on the description of the above problem, the purpose of this study was to developed valid chemistry practicum guide and kit for class XI second semester senior high school integrated inquiry model according to BSNP criteria and knowing the effectiveness of the chemistry practicum guide and kit integrated guided inquiry on student skills.

\section{METHOD}

The study was conducted in Medan State University, MAS Muta'allimin Aceh Besar and SMAN 1 Sukamakmur Aceh Besar in October 2017 - April 2018. The sample in this study is 2 Chemical practicum guide with different publisher, guided practicum guide, 22 class students XI MIA 1 MAS Muta'allimin Aceh Besar, 5 chemistry teachers, 3 peer review, and 2 lecturers of chemistry of Master Degree Program in Graduate Chemistry State University of Medan. Sample selection in study using purposive sampling technique.

This study type is research development with ADDIE (Analysis, Design, Development, Implementation, and Evaluation). The data obtained in the analysis phase is by analyzing the chemistry guide book of class XI SMA / MA Semester II from 2 different publishers. At the design stage, the practicum guide and kit that will be developed are prepared in the form of initial design. Some of the plans include preparing the framework of the guidance and the pratikum kit, determining the systematic development of practicum guide and kit, as well as designing the guidance view and the practicum kit. In the development stage, data collection is carried out in the form of validation from guides and practice kits that have been developed. At the implementation stage, the guidance and the chemistry practicum kit developed in implementation to 22 high school students of SMA X then perform student skill observation. In the evaluation phase the researchers evaluated the guides and the practicum kit based on the overall activities that have been done so that the product produced in the form of guidance and innovative laboratory kits for class XI SMA / MA Semester II integrated guided inquiry model.

Data obtained by questionnaire is processed by means of descriptive statistics. The equation used to calculate the results of questionnaires is the average calculation proposed [2] namely:

$$
\overline{\mathrm{X}}=\frac{\sum \mathrm{X}}{\mathrm{n}}
$$

$\overline{\mathrm{X}}=$ Average value

$\mathrm{x}=$ The number of validator / test subject answers

$\mathrm{n}=$ Number of validators / test subjects

\section{RESULTS AND DISCUSSION}

The first stage in this study is to analyze the guide lab chemist $\mathrm{A}$ and publisher $\mathrm{B}$ in circulation. The analysis was conducted to determine the feasibility level of the practicum both from the content feasibility aspect, language feasibility, feasibility of presentation, and feasibility of graduation in accordance with BSNP standard that has been modified for practical guidance. The results of the lab study guide can be seen in Figure 1. 


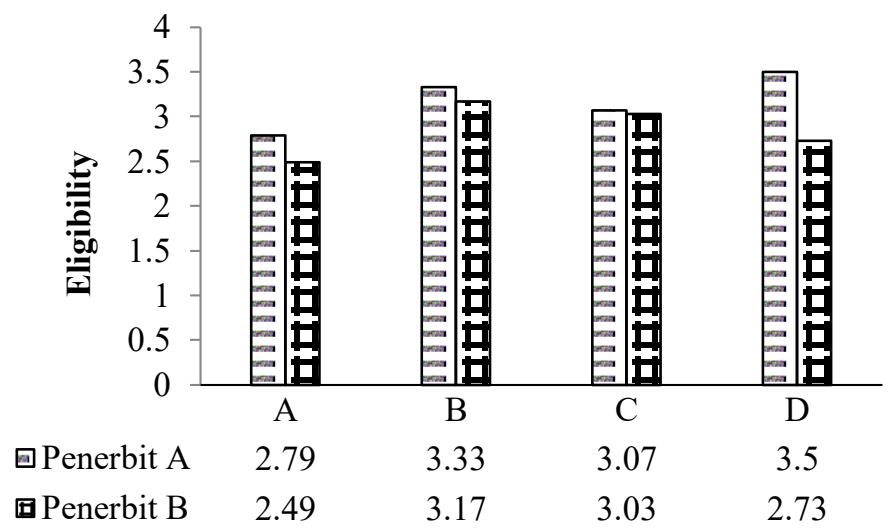

Fig 1 Graph of Preliminary Practicum Guide Analysis Results Publisher A and B

Information:

\section{A: Eligibility of content \\ B: Language eligibility \\ C: Feasibility of presentation \\ D: Feasibility of graffiti}

Result of analysis of chemistry chemistry guide of SMA XI Semester II based on BSNP showed that the average value of practicum guide from publisher A of 3.17 is quite feasible to be used and publisher B of 2.86 means it is quite feasible to be used, but in both guides there are still some parts that need to be added.

In the development phase, the first step is to describe indicators based on core competencies and basic competencies in the 2013 curriculum. Afterwards, designed any experiments that will be incorporated into the developed practice guide. The subjects developed in this practical guide are acid-base, acidbase titration, salt hydrolysis, buffer solution, solubility and solubility product, and colloids. Furthermore, an integrated guidebook for practicum model of guided inquiry and the availability of a practicum kit.

The developed chemistry practicum guide not only integrated with guided inquiry model but also equipped with introduction, contents list, curriculum analysis 2013, chemical introduction, chemical introduction, laboratory order, laboratory safety, developed experiments, and bibliography . The components of the experiment compilers include material pages, experimental titles, experimental purposes, theoretical basis, formulate problems, formulate hypotheses, collect data, tools and materials, work methods, test hypotheses, observations, questions and tasks, formulate conclusions, , student performance appraisal, and bibliography.
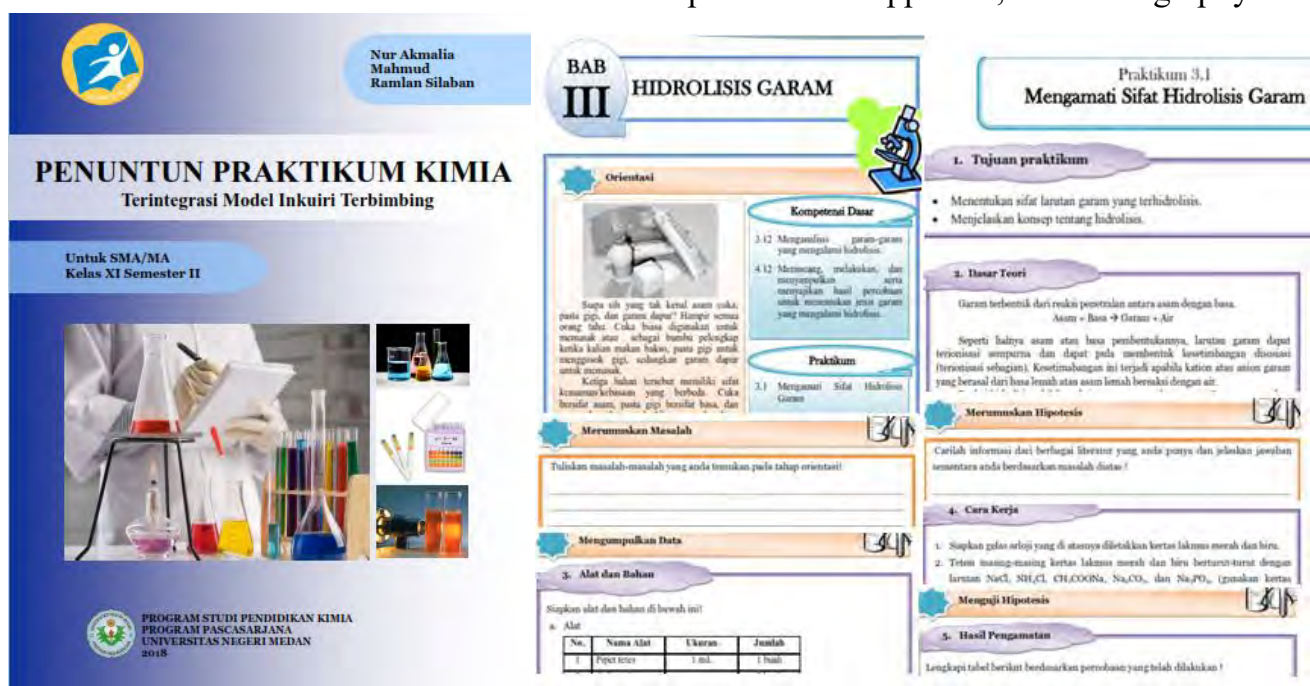

Fig 2 Practical Guide 
The experimental kit developed consisted of three practicum contained in the practicum guide ie salt hydrolysis, buffer solution, solubility and solubility product. In the Tool and the materials needed for the three labs are all neatly arranged in the box. Inside this box there is also a manual on the use of a practicum kit which lists the tools and how they are used, how-to safety, materials, and experimental work.

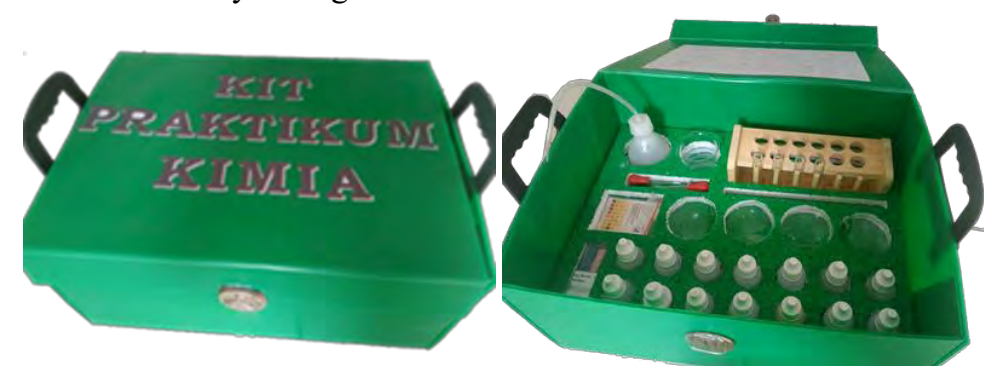

Fig 3 Practicum Kit

To produce guides and practice kits that are eligible for use must go through the validation process. The feasibility level of the developed chemistry guide can be seen in Figure 4.

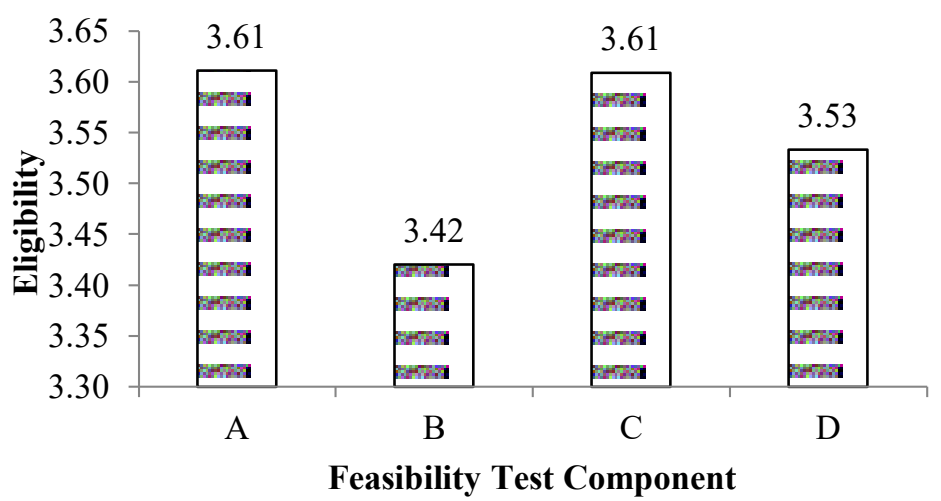

Fig 4 Graph of Preliminary Guidance Feasibility Analysis Result Developed

Information:
A: Eligibility of content
B: Language eligibility
C: Feasibility of presentation
D: Feasibility of graffiti

The result of the analysis of the chemistry practicum developed has shown that the mean value of 3.54 means that the practicum guide developed is very feasible to be used. In line with [8] indicating that the basic chemistry lab guide I integrated the inquiry approach is well worth using. This is evidenced from the validation results that have an average of 3.85 which means the practical guide is worth using.

The feasibility level of the chemistry practicum guide kit developed can be seen in Figure 5. 


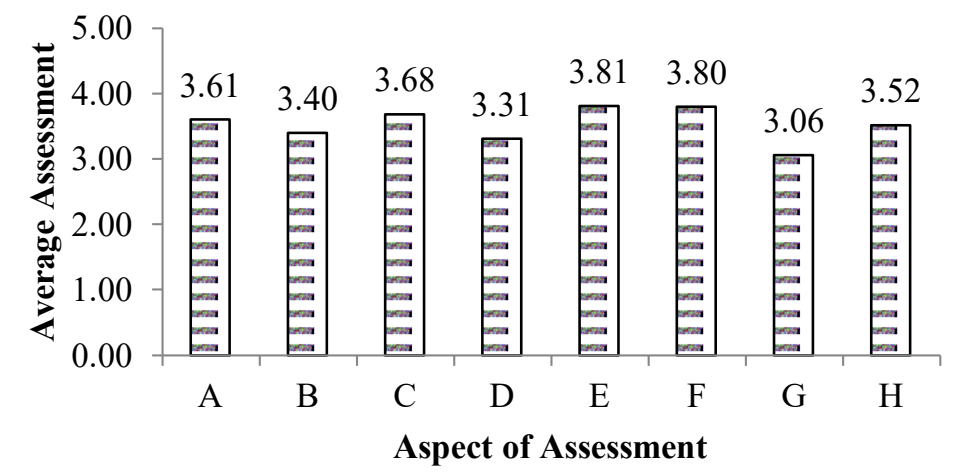

Fig 5 Graph of Average Feasibility Level of the Practicum Kit

Information:

A: Linkage with subject matter

B: Educational value

$\mathrm{C}$ : Device resistance

D: The accuracy of the tool

E: Tool efficiency

F: Security for students

G: Aesthetics

H: Box kit
The results of the experimental chemistry kit analysis developed show that the mean value of 3.54 means that the practicum kit developed is very feasible to be used. [10] stated that the practicum kit as a learning medium on chemical equilibrium material with inquiry-based LKS is feasible to be used on validity requirements, based on the content validity and the validity of the construct obtained an average percentage of $77.07 \%$ with valid criteria.

The last stage is the implementation stage, this stage is done to determine the effectiveness of the use of guidance and chemistry lab kit developed to the students skills. The data of students' skill observation at the time of practicing salt hydrolysis can be seen in Figure 6.

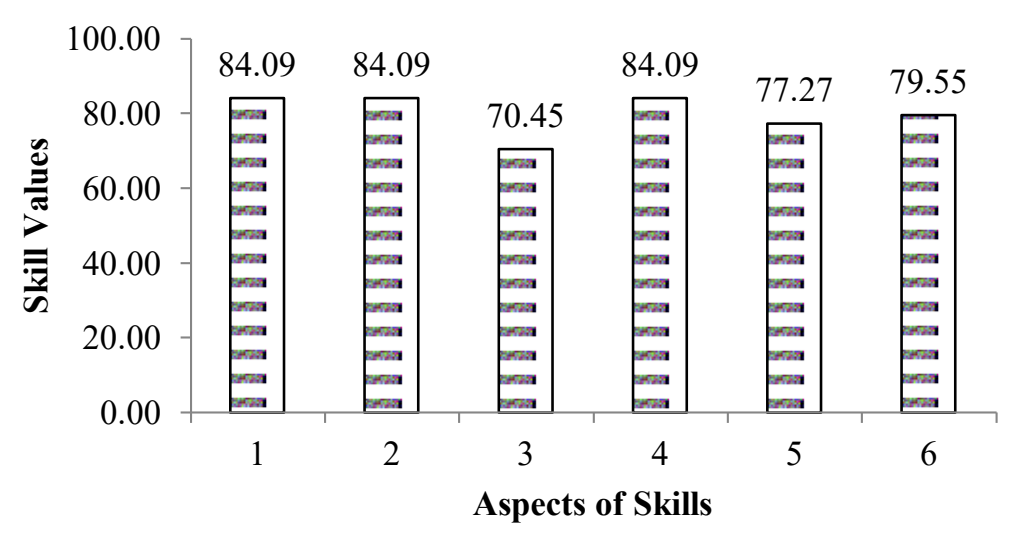

Fig 6 Graph of Observation Results of Student Skills Assessment During Practicum

Information:

1 : Prepare tools and materials in accordance with the practice procedure and in a clean condition
2 : Perform working procedures systematically

3 : Using practicum tools correctly and appropriately.

4 : Record observations made correctly and in detail in the observation table 
5 : Clean the tools and workplace used in the lab to observe the salt hydrolysis properties and rearrange them into the kit boxes provided

6 : Produce a practicum report observing the salt hydrolysis properties

The average score of the students' skills at the time of practicum based on the six indicators was 79.92 with good category. According to [8] basic chemistry lab guide I integrated the student's easy-to-understand inquiry approach. This can be seen from the results of affective and psychomotor assessment of students is good with the average affective rating of 2.5 and the average and average psychometric aspects of 2.34. The result of learning on cognitive aspect of students got pretest average equal to 69,31 and average postes equal to 82,73 . This proves that the use of integrated basic chemistry lead guide I can improve students' learning outcomes in both cognitive, affective and psychomotor aspects.

\section{CONCLUSION}

1. The feasibility level of the chemistry guide of SMA / MA class XI semester II which circulated from 2 different publishers have valid category, but there are some components from guidance that need to be done development.

2. Chemistry practicum guide developed has a very valid category, so it is worthy to be used in chemistry learning.

3. The developed practicum kit has a very valid category, so it is worthy of use in chemistry learning.

4. The effectiveness of use the chemistry practicum guide and kit on student skills shows an average value greater than the KKM score of 73 .

\section{REFERENCES}

[1] Abrahams, I. dan Millar, R. (2008). Does practical work really work? A study of the effectiveness of practical work as a teaching and learning method in school science. International journal of science education, 30(14), 19451969.

[2] Arikunto, S. (2010). Prosedur Penelitian Suatu Pendekatan Praktik. Jakarta: PT. Rineka Cipta.

[3] Bradley, J. D., Durbach, S., Bell, dan Mungarulire, J. (1998). Hands-On Practical Chemistry for All-Why and How?. Journal of Chemical Education, 75(11), 1406-1409.

[4] Deli, A. C. (2017). Pengembangan Penuntun Praktikum Inovatif Terintegrasi Model Pembelajaran Inkuiri Terbimbing Pada Materi Reaksi Reduksi Oksidasi Terhadap Hasil Belajar Kognitif Dan Keterampilan Siswa Kelas X SMA. Tesis. Medan: Pascasarjana Universitas Negeri Medan.

[5] Epinur, Afrida, Syahri, W., dan Purwanti, I. (2015). Pengembangan Kit Praktikum Dan Lembar Kegiatan Peserta Didik (LKPD) Materi Laju Reaksi Untuk Siswa SMA. Prosiding SEMIRATA 2015 bidang MIPA BKS-PTN Barat, 418-424.
[6] Hofstein, A. dan Lunetta, V. N. (2003). The Laboratory in Science Education: Foundations for the Twenty-First Century. Laboratory In Science Education, 28-54.

[7] Irmi, N. M, Adlim, dan Rahmayani, R. F. (2017). Pengembangan Penuntun Praktikum Kimia Dasar Ii Berbasis Inkuiri Terbimbing Pada Materi Reaksi Redoks Dan Elektrokimia. Jurnal Ilmiah Mahasiswa Pendidikan Kimia, 2(1), 27-34.

[8] Lubis, L. T., Silaban, R., dan Jahro, I. S. (2016). Pengembangan Penuntun Praktikum Kimia Dasar I Terintegrasi Pendekatan Inkuiri. Jurnal Pendidikan Kimia, 8(2), 95-104.

[9] Mulyono. (2005). Pengembangan dan Implementasi Model Praktikum Kimia Berbasis Lingkungan Tempat Tinggal Siswa pada SMU di Bandung. Jurnal Pengajaran MIPA, 6(1), 61-73.

[10]Rusdianawati, D. dan Sukarmin. (2017). Pengembangan Kit Praktikum Sebagai Media Pembelajaran Untuk Melatihkan Keterampilan Proses Sains Berbasis Inkuiri Pada Materi Kesetimbangan Kimia Kelas XI. UNESA Journal of Chemical Education, 6(2), 308-314.

[11] Supasorn, S. (2012). Enhancing undergraduates' conceptual understanding of organic acid-base-neutral extraction using inquiry-based experiments. Procedia-Social and Behavioral Sciences, 46, 4643-4650.

[12]Wardani, S. (2008). Pengembangan keterampilan proses sains dalam pembelajaran kromatografi lapis tipis melalui praktikum skala mikro. Jurnal Inovasi Pendidikan Kimia, 2(2), 317-322.

[13]Xu, H., dan Talanquer, V. (2012). Effect of the level of inquiry of lab experiments on general chemistry students' written reflections. Journal of Chemical Education, 90(1), 21-28.

[14] Zulaiha, Hartono, dan Ibrahim, A. R. (2014). Pengembangan Buku Panduan Praktikum Kimia Hidrokarbon Berbasis Keterampilan Proses Sains Di SMA. Jurnal Penelitian Pendidikan Kimia, 1(1), 87-93. 